\title{
単一貯留施設による治水の安全度に関する理論的研究
}

\section{MATHEMATICAL ANALYSIS ON RISK IN FLOOD CONTROL BY A STORAGE FACILITY}

\author{
江藤 剛 治*.室田 明** \\ By Takeharu ETOH and Akira MUROTA
}

\begin{abstract}
To drain or to reserve? That is the question discussed in this paper. The capacities of drainage and storage facilities for flood control are determined to minimize the total cost under the condition that chance of flooding is less than a tolerable level. An analytical expression of the chance constraint for a flood control system with a storage facility is presented.

The capacity of a drainage facility is evaluated based on frequency analysis of "peak discharge" of floods. The capacity of a storage facility may be reasonably evaluated through frequency analysis of "total runoff" of floods. Thus, characteristics of the flood-chance constraint are analyzed in view of the joint distribution of peak discharge and total runoff. Consequently, simplified expressions of the constraint are presented for practical applications.
\end{abstract}

\section{1.はじめに}

貯留施設をもたず，排水施設のみによって洪水を排水 する治水システムにおいては, ピーク流量の確率分布に 基づいて治水安全度を評価する.逆に排水施設をもたず, 貯留施設のみによって洪水を制御する治水システムで は,洪水の全量を貯留施設で貯えなければならないから, ピーク流量ではなく, 個々の洪水の総流量を確率評価し, 所与の安全度に対応する総流量を貯えることができるだ けの容量をもつ貯留施設を築造しなければならない. 以 上から直観的に予想されるように，貯留施設が排水施設 上同程度の治水機能を果たすような治水システムでは。 各洪水ハイドログラフのピーク流量と総流量の結合確率 分布に基づいて治水安全度を評価しなければならない.

この問題は, 治水安全度の確率評価が提唱されはじめ た当時から指摘されていたが，いまだに末解決の問題で ある11.これは次のような理由によるものと考えられる. 一般に結合確率分布に基づく確率統計解析は, 複雑な理 論や数值計算を必要とする. 一方実務に用いる手法はで

* 正会員 工博 近畿大学教授 理工学部土木工学科 ( ₹577 東大阪市小若江 3-4-1)

** 正会員 工博 大阪大学教授 工学部土木工学科 ( ₹565 吹田市山田丘 2-1)
きる限り明快かつ簡便なものでなければならない。この 2 つの相反する要求を同時に満たすのは容易ではない.

著者らは,「厳密な解析, わかりやすい結果」を指針 として表記の問題について理論的検討を行い,すでに次 のような研究成果を得た ${ }^{2 \nmid \sim 4)}$.

(1) 貯留施設と排水施設をもつ治水システムの治水安全 度表示の手法として「等危険度線」という概念を提示し た。等危険度線は治水安全度を一定の水準に保つに必要 な，排水施設容量と貯留施設容量の関係を表わす.

(2) 単一排水施設と単一貯留施設から構成される治水シ ステム (Fig. 1 (a) 参照, 以後 module 1 とよぶ) に対 して等危険度線の方程式を導き, 理論的な検討によりそ の基本的な性質を明らかにした。

(3) その結果に基づいて, module 1 の治水システムに 対して，実際に等危険度線を描くための簡便な手法を提 示した (以上, 文献 2 ), 3) 参照).
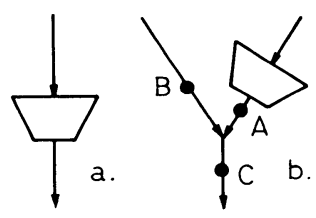

a: moduie 1

b: module 2

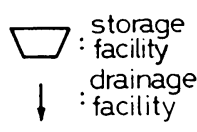

Fig. 1 Modules of flood control systems. 
(4)これを実際の遊水地計画に適用し, 等危険度線によ る治水安全度評価が，実用上非常に有用な手法であるこ とを示した

本論文では等危険度線の理論を, 貯留施設下流に残流 域がある場合 (Fig. 1(b) 参照, 以後 module 2 とよぶ) に対して拡張する。

実際の治水システムは複数の排水施設と貯留施設で構 成される.このような治水システムの安全度を一般的か つ厳密に評価することは困難である。一方, 貯留施設が 単一の場合については, 樹枝状の河道網を単純化して module 2 で近似することができる．また適当な条件下 では, 複数の貯留施設を有する治水システムが module 2 の治水システムと等価であることを証明することがで きる ${ }^{5)}$. よって等危険度線の理論を残流域がある場合に 対して拡張することの意義は大きい.

まずできる限り厳密な理論解析により, 等危険度線の 式を導き，その性質を調べる. 次にその結果に基づいて, 実際に等危険度線を描くための簡便な手法を提示する.

\section{2. 記号・定義・仮定}

用語・仮定などを説明する (以下 Fig. 2 参照).

貯留施設をもつ流域を貯留流域,他方を残流域とよぶ. また排水施設・貯留施設の容量を排水容量 ・貯留容量と よぶ.たとえば，排水施設として河道を考える場合は排 水容量は疎通能, ポンプを考える場合はポンプ容量など. 河道を例にして説明すると， A， B，C点はそれぞれ， 貯留施設から合流点まで, 残流域, 合流点から最下流端 まで, の各河道の中で疎通能 (排水容量) が最小の地点.

$y$ を自然流量のピーク流量, すなわち貯留施設でコン トロールしていない流量のピーク流量, $y^{\prime}$ をコントロー ルした流量のピーク流量とする． $z$ は総流量を表わす. 洪水継続時間を $x$ で表わす.

$z^{\prime}$ は貯留施設の貯留量, $d$ は目標放流量を表わす.

0 は施設容量, A， B , C は地点を表わす添字. たと えば $z_{0}, y_{0 c}, y_{c}$ はそれぞれ貯留容量, C 点の排水容量, C 点の自然ピーク流量を表わす.

F., f. は, 添字 (・) を変数とする確率分布関数, 確率密度関数.

以下の定義・仮定を用いる.

（i）安全度評価に関する定義

(1) 次の条件が満たされるとき,「治水に失敗した」 と定義する．貯留施設が満水になったとき，あるい は評価基準点のコントロール後のピーク流量がその 点の排水容量を超えたとき。

(2) 治水に失敗する確率を「システムの危険度」とよ び, $P_{F}$ で表わす.「システムの安全度」を $P_{S}\left(=x_{0}\right.$ $\left.=1-P_{F}\right)$ で表わす.
(3) $P_{s}$ が最大になる状態を「最適」とよぶ.

(4) 評価基準点は 1 点であるとする.この場合 $\mathrm{C}$ 点を 評価基準点とする.

(ii）放流方式に関する仮定

(5) 貯留施設の操作方式は「一定量放流方式」とする.

（iii） ハイドログラフに関する仮定

(6) ハイドログラフは変形せずに流下する.

(7) 貯留流域流量と残流域流量の線形重ね合わせ可 能.

(8) 合流点で貯留流域と残流域流量に到達時差なし.

(9) 任意の時点の, 貯留流域自然流量と残流域自然流 量とは完全線形従属 (比例).

(10) ハイドログラフの三角形近似可能.

(1)について補足する (Fig.2(b) 参照). 貯留施設が 満水になると $\mathrm{C}$ 点流量は急激に立ち上がる. 残流域があ るとき, 満水になる時点 $t_{F}$ がピーク発生時点 $t_{P}$ より十 分遅れる場合には, $t_{F}$ における流量 $y_{t F}$ はコントロール 後のピーク流量 $y_{c}^{\prime}$ よりも小さくなる.この場合, $y_{c}^{\prime} か ゙$ 排水容量 $y_{0 c}$ よりも小ならば，実際には洪水被害は生じ ない.しかし貯留施設が満水になるという異常事態が生 じているので, この場合も失敗の側に含める.

(5)ついて補足する．著者らはすでに一定率放流方式 に対する等危険度線の基礎方程式も与えている ${ }^{3)}$. しか し大洪水を対象とし，かつ計画論を考える場合は一定量 放流を仮定する方が現実的である．また横越流方式など の構造型式に対しては，この仮定は無理なく成立する.

(6) (9)より, 貯留流域と残流域の洪水継続時間 $x$ は 等しい。また,

$$
\left.\begin{array}{l}
y_{C}=y_{A} / k_{A}=y_{B} / k_{B}, \\
y_{C}=y_{A}+y_{B}, \quad k_{A}+k_{B}=1
\end{array}\right\}
$$

ここに, $k_{A}, k_{B}$ は $y_{C}$ と $y_{A}, y_{B}$ の比を表わす定数.

等危険度線を次のように定義する。

最適解を添字*で示す. 排水容量 $y_{0 c}$, 貯留容量 $z_{0}$ を固定し， $P_{F}$ を最小 $\left(P_{s}\right.$ を最大) とするように目標放 流量 $d$ を決めると, このときの $d$ の值 $d_{*}$ が最適目標
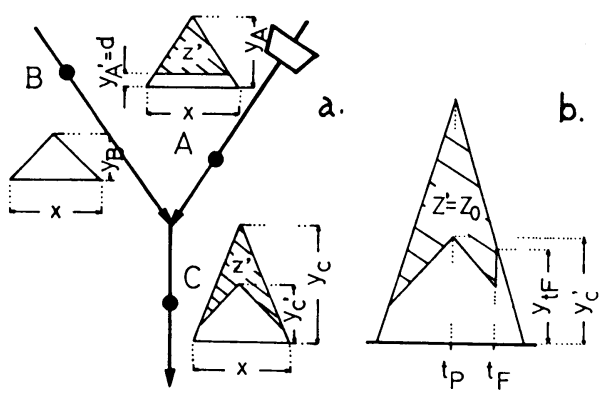

Fig. 2 Schematic explanation of symbols, definitions, and assumptions. 
放流量となる，すなわち $d *$ は次式を満たす。

$P_{F *}=\min _{d}\left(P_{F} \mid y_{0 c}, z_{0}\right)$

逆に $P_{F *}$ を所与の安全度（以後 $x_{0}$ で表わす）に保ち, 式（2）を満たす $\left(y_{0} c, z_{0}\right)$ の関数関係を表わす方程 式を求めれば，これが等危険度線の方程式である.

module 1 では, 最適目標放流量 $d_{*}$ は排水容量 $y_{0}$ に 等しいことは自明である. よって式 $(2)$ の最小化は, module 1 に対する理論では不要となる.

\section{3. 理論}

（1）基 礎 式

本文中では主要な結論のみを示す.証明は補遺に示す。 仮定より，危険度 $P_{F}$ ，および貯留施設の築造が意味 をもつための目標放流量 $d$ の範囲は (補遗 1 参照),

$$
\begin{aligned}
& P_{F}=\operatorname{Prob}\left\{\left(y_{c}^{\prime}>y_{0 c}\right) \cup\left(z^{\prime}>z_{0}\right)\right\} \\
& =\operatorname{Prob}\left(z^{\prime}>z_{0}\right) \\
& +\operatorname{Prob}\left\{\left(d+y_{B}>y_{0 c}\right) \cap\left(z^{\prime} \leqq z_{0}\right)\right\} \\
& =P_{F 1}+P_{F 2}
\end{aligned}
$$

$0 \leqq d \leqq k_{A} y_{0 c}$

ここに， $P_{F 1}, P_{F 2}$ は式 ( 3 ) の右辺第 1 項, 第 2 項 である. 物理的な意味は次のとおりである.

$P_{F 1}=$ [貯留施設が満水になる確率 $]$,

$P_{F 2}=$ [貯留施設が満水にならないという条件下でC 点 で越流する確率]

式（3）を式（2）に代入し, 次のように置く.

$P_{F *}=1-x_{0}$

これが module 2 に対する等危険度線の基礎式であ る.

\section{（2）排水容且 $\boldsymbol{y}_{0 c}$ の上下界}

a) $z_{0} \rightarrow 0$ の場合

$P_{F 2}$ は 0 となる. また $\left(z^{\prime}>0\right)$ と $\left(y_{A}>d\right)$ とは同値 である.よって極限では，

$P_{F}=\operatorname{Prob}\left(y_{A}>d\right)$.

$d$ が大きいほよ゙ $P_{F}$ は小さい. よって式 $(4)$ より,

$$
d_{*}=k_{A} y_{0 c}
$$

$P_{F *}=\operatorname{Prob}\left(y_{A}>k_{A} y_{0 c}\right)=\operatorname{Prob}\left(y_{c}>y_{0 c}\right)$

$$
=1-F_{y c}\left(y_{0 c}\right) \text {. }
$$

式（8）を（5）に代入すれば,

$$
y_{0 c}=y_{0 c}^{v}
$$$$
d_{*}=k_{A} y_{0 c}^{v}=y_{0 A}^{v}
$$

$y_{0 c}^{U}=\mathrm{F}_{y C}^{-1}\left(x_{0}\right), \quad y_{0 A}^{U}=\mathrm{F}_{y A}^{-1}\left(x_{0}\right)$

以上より， $x_{0}$ を一定に保って $z_{0}$ を 0 に近づけるとき， $y_{0 c}$ はその上界 $y_{o c}^{v}$ に近づくことがわかる. すなわち， 等危険度線は $\left(y_{0 c}, z_{0}\right)=\left(y_{0 c}^{U}, 0\right)$ を通る。このとき の最適目標放流量は式 $\left(7^{\prime}\right)$ で与えられる.

b) $z_{0} \rightarrow \infty$ の場合

$P_{F 1}$ は 0 となる．また $z^{\prime} \leqq z_{0}$ は常に成立するから，

$$
P_{F}=\operatorname{Prob}\left(y_{\mathrm{B}}>y_{\mathrm{oc}}-d\right)
$$

$d$ が小さいほど $P_{F}$ は小. よって, 式（1 ), ( 4 ), ( 5 ), （9）などを用いて，

$$
\begin{aligned}
& d_{*}=0 \\
& P_{F *}=1-F_{y c}\left(y_{0 c} / k_{B}\right) \\
& y_{0 c}=k_{B} \mathrm{~F}_{y c}^{-1}\left(x_{0}\right)=k_{B} y_{0 C}^{U} \\
& =\mathrm{F}_{y_{B}}^{-1}\left(x_{0}\right)=y_{0 B}^{U}
\end{aligned}
$$

以上より，3. (3), b) に示すような特別の場合を除い て，一般的には，等危険度線はFig. 5(a) に示すような 形状となる。

\section{（３）３角形のハイドログラフを仮定する場合}

\section{a) 一 般 式}

八イドログラフの形状を仮定すると，より具体的に等 危険度線の方程式を求めることができる.

ここでは 3 角形のハイドログラフを仮定する．ただし 継続時間 $x$, ピーク流量 $y$ ともに確率変数とする， $x$, $y$ の組合せによって, 尖ったハイドログラフ,なだらか なハイドログラフ等さまざまなハイドログラフがある確 率法則に従って生起することになる. Fig. 3 で

$$
z^{\prime}=1 / 2 \cdot k_{2} x\left(y_{1}-d\right)^{2} / y_{A}
$$

$k_{2}$ は実際の継続時間と 3 角形近似ハイドログラフの継 続時間の比で, 定数とする.

よって, $z^{\prime}>z_{0}$ の条件は,

$x>2 z_{0} / k_{2} \cdot y_{A} /\left(y_{A}-d\right)^{2}$

また, $\left(d+y_{B}>y_{0 c}\right)$ の条件は,

$y_{A}>k_{A} / k_{B} \cdot\left(y_{0 c}-d\right)$

式（14），(15）を式（3）に代入すれば,

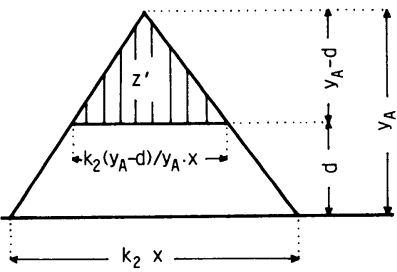

Fig. 3 Triangular hydrograph for a storage basin.

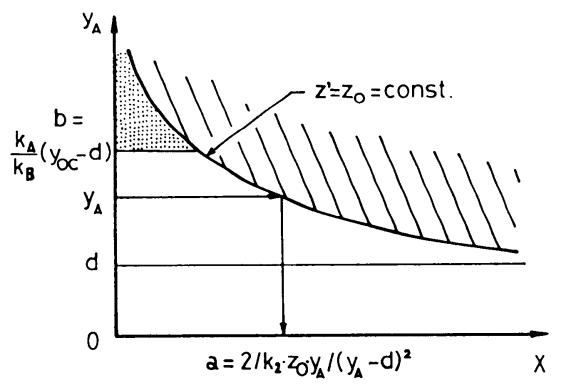

Fig. 4 Domain of integration for module 2 . 


$$
\begin{aligned}
P_{F}= & \operatorname{Prob}\left\{x>2 z_{0} / k_{2} \cdot y_{A} /\left(y_{A}-d\right)^{2}\right\} \\
& +\operatorname{Prob}\left[\mid y_{A}>k_{A} / k_{B} \cdot\left(y_{0 c}-d\right)\right\} \\
& \left.\cap\left\{x \leqq 2 z_{0} / k_{2} \cdot y_{A} /\left(y_{A}-d\right)^{2}\right\}\right] \cdots
\end{aligned}
$$

Fig. 4 は, 式 (16) を $\left(x, y_{A}\right)$ 面上にプロットした ものである. 右辺第 1 項が斜線部，第 2 項が点を打った 部分となる. module 1 の場合 ${ }^{3}$ と比較すると，点を打っ た部分が付加されることになる.

よって $\left(x, y_{A}\right)$ の結合確率密度関数 $\mathrm{g}\left(x, y_{A}\right)$ が与 えられるとき，

$$
\begin{aligned}
P_{F}= & \int_{d}^{\infty} \int_{a}^{\infty} \mathrm{g}\left(x, y_{A}\right) \mathrm{d} x \mathrm{~d} y_{A} \\
& +\int_{b}^{\infty} \int_{0}^{a} \mathrm{~g}\left(x, y_{A}\right) \mathrm{d} x \mathrm{~d} y_{A}
\end{aligned}
$$

ここに,

$a=2 z_{0} / k_{2} \cdot y_{A} /\left(y_{A}-d\right)^{2}$

$b=k_{A} / k_{B} \cdot\left(y_{0 c}-d\right)$

b) $x, y_{A}$ が完全線形従属の場合

$k_{1}$ を比例定数とすれば,

$y_{A}=k_{1} x$

式（18）を（16）に代入して変形すれば，Fig. 5(b)

に示すように，等危険度線は二次放物線と $z_{0}$ 軸に平行 な直線で表わされることがわかる（補遗２）。ただし， 図の下半分は最適放流量を示す (Fig.5(a), Fig.6も同 様).すすおち次の曲線を境界として解の性質が変わる. $z_{0}=1 / 2 k_{2} / k_{1}\left(k_{A} / k_{B} y_{0 c}\right)^{2}$

式（19）の境界より上部を領域 I，下部を領域 II とよ ぶことにする．各領域に対して等危険度線，最適目標放 流量は次のしおりである.

\section{(i ) 領域 I}

$$
\begin{gathered}
y_{0 c}=y_{0 B}^{\nu} \text { のとき, } \\
z_{0} \geqq z_{0 A}^{\nu} \\
d_{*}=0
\end{gathered}
$$

\section{(ii ) 領域 II}

$$
\begin{aligned}
& y_{0 B}^{U}<y_{0 c} \leqq y_{o c}^{U} \text { のとき, } \\
& z_{0} / z_{0}^{u}=\left\{\left(y_{0 c}^{u}-y_{0 c}\right) / y_{0 c}^{u}\right\}^{2} \\
& d_{*}=y_{0 C}-y_{O B}^{U} \\
& \text { ここに, } \\
& \left.\begin{array}{rl}
z_{0}^{U} & =1 / 2 k_{2} / k_{1}\left(y_{0 c}^{U \prime}\right)^{2} \\
z_{0 A}^{U} & =1 / 2 k_{2} / k_{1}\left(y_{0 A}^{U}\right)^{2} \\
& =k_{A}^{2} \cdot z_{0}^{U}
\end{array}\right\}
\end{aligned}
$$

Fig. 5(b) ((20)〜 (22)) は, module 1 の解を $y_{0 c}$ 軸 の正方向に $y_{0 B}^{U}$ (安全度 $x_{0}$ に対応する残流域のピーク流 量）だけ平行移動したものにほかならない。この結果が 後述の簡便法 II の理論的根拠の 1 つである.

これらの式のもつ実際的な意味について触れておく。 領域 Iでは貯留容量は過大になっている，すなわち， $z_{0}$ を式（19）で表わされる境界値まで下げても，安全

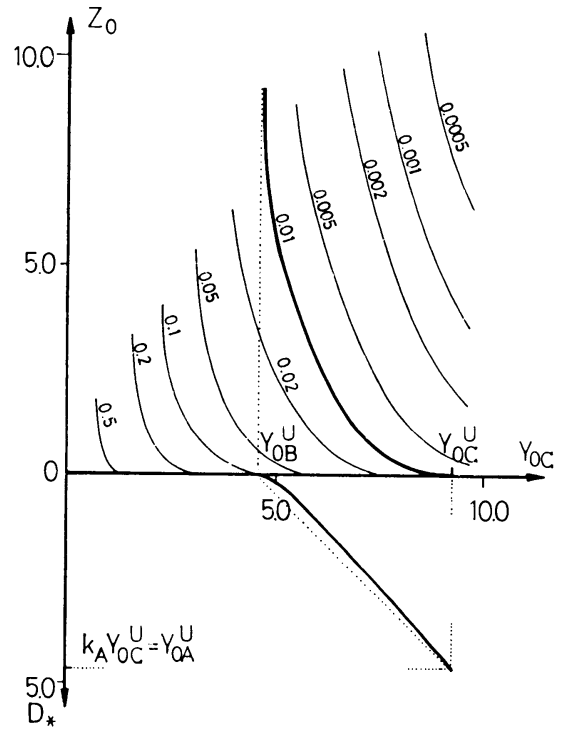

Fig.5(a) A typical example of 'Equi-risk lines'. ( $x$ and $y_{A}$ are independently and exponentially distributed. Eq. (24), (25), $k_{A}=k_{B}=1 / 2$ )

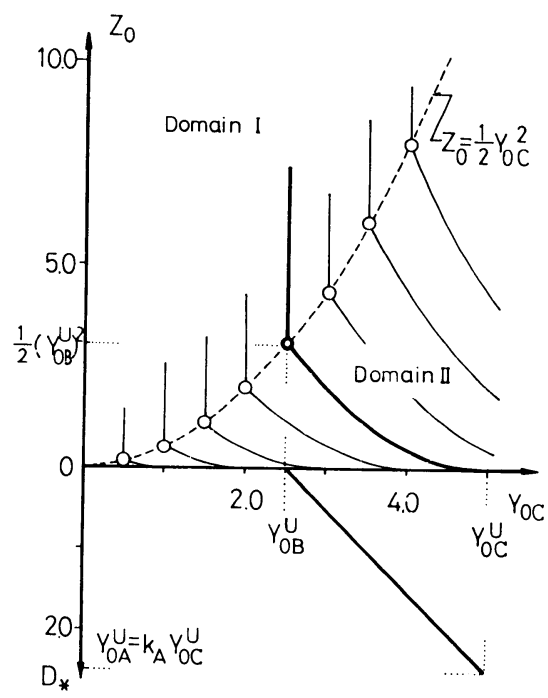

Fig. 5(b) An equi-risk line for the case where $x$ and $y_{A}$ are linearly-dependent. $\left(Z_{0}=z_{0} /\left(k_{1} k_{2}\right), Y_{0 c}=y_{0 c} / k_{1}, D_{*}\right.$ $=d_{*} / k_{1}, \quad k_{A}=k_{B}=1 / 2, \quad Y_{0 A}^{U}=Y_{0 B}^{U}=y_{0 A}^{\nu} / k_{1}$, Eq. (19) $-(22))$

度は変わらない。よってすでにこの領域にある現㬰の治 水システムについては, 早急に下流河道を整備し, 領域 IIに入るようにして治水安全度を高めるか，過㮃容量分 を利水に振り替えるなどの対策を講じる必要がある．遊 水地の段階的拡張計画などにおいては，やむを得ず下流 の河道整備が遅れる場合には，現況の疎通能 $y_{0 c}$ を式 （19）に代入して得られる貯留容量を，暫定的に当面の 
遊水地規模とすればよい.

最適目標放流量について補足する。領域 I では貯留容 量過大であるから, 当然目標放流量は 0 である. 領域 II では $y_{0 B}^{U}$ は安全度 $x_{0}$ に対応する残流域ピーク流量であ る. よって原則的には, 下流の排水容量からこの值を差 し引いた量を, 貯留施設から放流すればよい. また貯留 施設が計画よ゙おりに完成しても，下流の排水施設整備が 終わるまでは，当初の計画放流量を目標放流量とするの ではなく, 排水施設の整備状況, すなわち $y_{0 c}$ に応じて, 式 (21)の $d_{*}$ 暫定的な目標放流量とすべきである.

ただし以上の結果は, 洪水継続時間 $x$ と残流域ピー ク流量 $y_{A}$ が完全線形従属という特殊な条件に対して導 かれたものである.より一般的な条件下における等危険 度線の性質を調べるために，引き続き以下に示すような 理論解析を行う.

c） $x, y_{A}$ が独立かつともに指数分布に従う場合

$\mathrm{g}\left(x, y_{A}\right)=\mathrm{f}_{x}(x) \mathrm{f}_{y_{A}}\left(y_{A}\right)$

$\mathrm{f}_{x}(x)=\beta_{x} \exp \left(-\beta_{x} x\right)$

$\mathrm{f}_{y_{A}}\left(y_{A}\right)=\beta_{y_{A}} \exp \left(-\beta_{y_{A}} y_{A}\right)$

ここに， $\beta_{x}, \beta_{y_{A}}$ は $x, y_{A}$ の尺度母数.

式（23）を（17）に代入し無次元化して整理すれば,

$$
\begin{aligned}
& P_{F}=\int_{D}^{B} \exp (-Y-A) d Y+\exp (-B) \\
& P_{F *}=\min _{0<D \leqq k_{A} Y_{0 C}}\left(P_{F} \mid Y_{0 C}, Z_{0}\right)
\end{aligned}
$$

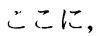

$$
\begin{aligned}
& X=\beta_{x} x, \quad Y=\beta_{y A} y_{A}, \quad D=\beta_{y A} d, \\
& Y_{0 C}=\beta_{y_{A}} y_{0 c}, \quad Z_{0}=1 / k_{2} \beta_{x} \beta_{y_{A}} z_{0} \\
& A=\beta_{x} a=2 Z_{0} Y /(Y-D)^{2} \\
& B=\beta_{y_{A}} b=k_{A} / k_{B}\left(Y_{0 C}-D\right)
\end{aligned}
$$

通常の条件下の等危険度線はおおむね, この独立の場 合の解と先述の完全線形従属の場合の解の中間的な性質 をもつもの之考えられる.よってこの 2 種の解を比較検 討すれば等危険度線の一般的な性質をある程度明確にす ることができる.

ただし完全線形従属の場合と違って, 式 (24) の陽解 を求めることはできなかった。よって解の性質を詳細に 調べるには，若干の数值計算を必要とする. Fig. 5(a) に式 (24) の数值計算結果の例を示す.

d) 貯留容量が大きいときの等危険度線

$$
\begin{aligned}
P_{F}= & \operatorname{Prob}\left(z^{\prime}>z_{0}\right) \\
& +\operatorname{Prob}\left\{\left(d+y_{B}>y_{0 c}\right) \cap\left(z^{\prime} \leqq z_{0}\right)\right\} \\
& \sim \operatorname{Prob}\left(z^{\prime}>z_{0}\right)+\operatorname{Prob}\left(d+y_{B}>y_{0 c}\right)
\end{aligned}
$$

$y_{0} c, z_{0}$ が一定の条件のもとに, 式 (26) の $P_{F}$ を最 小とする $d$ の値 $d *$ は次の条件を満たす（以下補遗 3 参 照).

$$
-\frac{\mathrm{d} z_{0}}{\mathrm{~d} d} \cdot \frac{\partial P_{F 1}}{\partial z_{0}}=\frac{\partial P_{F 1}}{\partial \eta}
$$

式（27）を満たし，かつ $d_{*}=0$ となる条件は，

$s \cdot z_{0 A}^{U^{\prime}} / y_{0 A}^{U^{\prime}} \cdot \mathrm{f}_{z}\left(z_{0 A}^{U^{\prime}}\right)=\mathrm{f}_{y_{B}}\left(y_{0 c}^{L}\right) \cdots$

ここに, $s$ は定数 $(s=2 \sim 3)$. また,

$z_{0 A}^{U^{\prime}}=\mathrm{F}_{z}^{-1}\left(x_{01}\right), \quad y_{0 A}^{U^{\prime}}=\mathrm{F}_{y_{A}}^{-1}\left(x_{01}\right)$

$x_{01}$ は貯留流域の安全度.

残流域流量 $y_{B}$ のみがC 点に流入する場合の安全度を $x_{02}$ で表わす上,

$x_{02}=\mathrm{F}_{y_{B}}\left(y_{0 \mathrm{c}}^{i}\right)$

$\left(z_{0 A}^{U}, y_{0 C}^{L}\right)$ が式 $(28)$ （30）を満たすとき, 危険度

$P_{F *}^{\prime}$ および安全度 $x_{0}^{\prime}$ は,

$$
\begin{aligned}
& P_{F *}^{\prime}=2-\left(x_{01}+x_{02}\right) \\
& x_{0}^{\prime}=x_{01}+x_{02}-1 \cdots \cdots
\end{aligned}
$$

式 $(29)$ の’は， $x_{0}$ ではなく $x_{01}$ に対応する值である こと, 式 (31), (32) の’は, 近似解を意味する.

式 (28) の解を得るためには, 次の確率分布関数, 密 度関数が個々にわかっておればよい。

貯留流域について $\mathrm{F}_{y A}, \mathrm{~F}_{z}, \mathrm{f}_{z}$, 残流域について $\mathrm{f}_{y B}$. すなわち，結合確率分布に関する情報を全く必要とし ないという点が，実用上きわめて重要な性質である.

この結果が簡便法 I の理論的根拠である.

\section{（4）まと め}

貯留流域と残流域のハイドログラフの比例性等を仮定 すると, module 2 の等危険度線について, 一般的に次 のような式・性質が成り立つことを示した。

(1) 危険度，および等危険度線の一般式を示した（式 ( 2 ), ( 3 )).

等危険度線について，

(2) 存在範囲は $y_{0 B}^{U} \leqq y_{0 c} \leqq y_{0 c}^{U}$.

(3) $\left(y_{0 c}^{U}, 0\right)$ で， $z_{0}$ 軸に接する.

(4) $y_{0 c}$ がその下限值 $y_{0 B}^{U}$ に近づくとき， $z_{0}$ は無限大 となる.すなわち $z_{0}$ 軸に平行な直線 $y_{0 C}=y_{0 B}^{V}$ に漸 近するか完全に一致する.

(5) 貯留容量が十分大きいとき，最適目標放流量が満 たすべき条件を導いた（式 $(27))$.

(以上(2)〜(4)についてはFig. 5(a)，3. (2) 参照)

さらに，三角形ハイドログラフを仮定すると，次のよ うな式，性質を導くことができる.

（6) 等危険度線の方程式は, 洪水継続時間とピ--ク流 量の結合確率密度関数の 2 重積分により求めること ができることを示した（式 (17)).

(7) 洪水継続時間とピーク流量が完全線形従属の場合 の等危険度線は, $\left(y_{0 c}, z_{0}\right)=\left(y_{0 B}^{U}, z_{0 A}\right)$ で折れ曲り, $z_{0}$ 軸に平行な直線となる。 また $y_{0 B}^{U}<y_{0 c} \leqq y_{0 C}^{U}$ の範 用では，厳密に二次放物線となる（式（20)〜 (22), Fig. 5(b)).

８）洪水継続時間とピーク流量が独立かつともに指数 分布に従う場合の等危険度線の式の具体的な式形を 
示した（式 (24), (25)).

最適目標放流量 $d *$ については,

(9) $y_{0 c}=y_{0 c}^{U}$ のとき, $d_{*}=y_{0 A}^{U}$, $y_{0 c}=y_{0 B}^{U}$ のとき, $d_{*}=0$.

(式 $\left.\left(7^{\prime}\right),(10)\right)$.

(10) 上記77の場合には $d_{*}$ は $y_{0 B}^{U}<y_{0 c} \leqq y_{0 c}^{U}$ の範囲で $y_{0 c}$ の関数として直線的に変化する（式 $(21)$, Fig. 5(b)). 一般には，この值よりやや小さい値に なる (Fig. 5(a)).

(11) 上記(5)の条件下で, $d_{*}=0$ のとき, $\left(y_{0 c}, z_{0}\right)$ が 満たすべき条件式を導いた（式（28））．貯留流域の ピーク流量・総流量と残流域のピーク流量の確率分 布がわかっておればこの式を解くことができる.す なわち，この場合結合確率分布に関する情報は全く 必要ない。

\section{(5) 前提条件の緩和}

以上の結果はかなり限定された条件のもとに導かれた 結果である.より一般的な検討を行うには，前提条件を 緩和し，より実際に近い条件のもとに理論的検討を行え ばよい，前提条件についてはできるかぎり正確に記述し ているので, その緩和がよ゙のような実際現象と対応して いるか，また理論上どのような修正を必要とするかを把 握することは容易である。

\section{4. 等危険度線を描くための実際的な手法}

\section{（1）簡便法 I}

等危険度線は $\left(y_{0 c}^{U}, 0\right)$ を通ること， $z_{0}$ が大きいと きは近似的に式 $(28)$ を満たし，かつこのとき $d_{*}=0$ となるという性質を利用する (Fig. 6 破線参照).

(1) $\boldsymbol{x}_{01}$ の值を仮定する.

(2) 式 (29) より, $z_{0 A}^{U^{\prime}}, y_{0 A}^{U^{\prime}}$ を求め, これを $\mathrm{f}_{\boldsymbol{z}}$ に代 人して, 式 (28) 左辺の值を求める. $s=2$ とする.

(3) 式 (28) を満たす $y_{0 c}$ の值を求める.これを $y_{0 c}^{L}$ 之書く.

(4) 式 (30) より $x_{02}$ を求める.

(5) 式 (32) より $x_{0}^{\prime}$ を求める.

(6) 式 (9) より $y_{o c}^{U}$ を求める.

(7) $\left(y_{0 c}^{L}, z_{0 A}^{U}\right)$ と $\left(y_{0 c}^{U}, 0\right)$ を二次放物線で結ぶ.

(8) $z_{0} \geqq z_{0 A}^{U}$ の部分については $z_{0}$ 軸に平行な直線, $y_{0 c}$ $=y_{0 C}^{L}$ とする.

(9) $d_{*}$ と $y_{0 c}$ の関係については, 次の 2 点を結ぶ直 線で近似する.

$y_{0 c}=y_{0 c}^{U}$ のとき, $d_{*}=y_{0 A}^{U}$

$y_{0 c}=y_{0 c}^{L}$ のとき, $d_{*}=0$

（2）簡便法 II

直観的に理解しやすい方法として次のような方法が考 えられる (Fig.6一点, 二点鎖線参照).

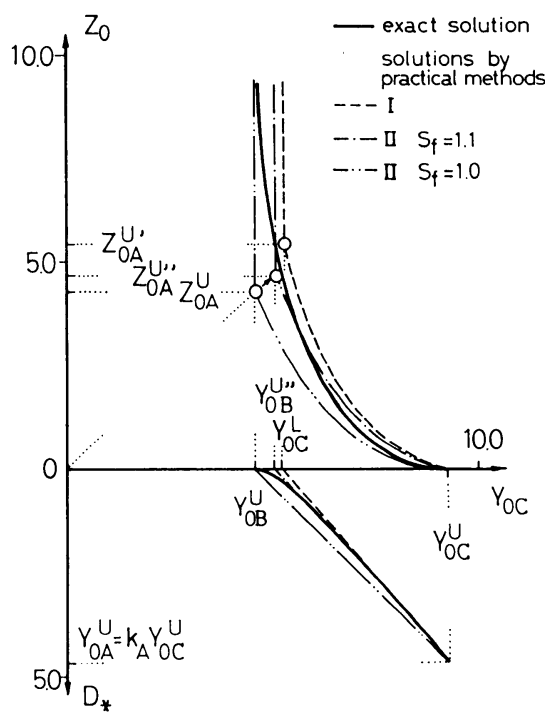

Fig. 6 Applicability of practical methods. (The same conditions as in Fig. 5(a))

安全度 $x_{0}$ が与えられたとき,Fig. 2 のC点において, まず $x_{0}$ に対応する残流域流量を流し得るだけの排水容 量 $\left(y_{0 B}^{U}\right)$ を確保する. 残りの排水容量 $\left(y_{0 c}-y_{0 B}^{U}\right)$ を 目標放流量 $d$ とし, 貯留施設が満水になる確率が $(1-$ $x_{0}$ ）となるように貯留容量 $z_{0}$ を定める. 後半の貯留容 量の評価においては, 貯留流域の流量のみを考え, module 1 に対する等危険度線の理論を適用する.

この方法はやや危険側の等危険度線を与える. たとえ ば, $y_{0 c}=y_{0 B}^{U}$ のよき $d=0$. この亡き上記の方法により 求めた貯留容量を $z_{0 A}^{U}$ と書くと,

$z_{0 A}^{U}=\mathrm{F}_{z}^{-1}\left(x_{0}\right)$

一方，前章のまとめ(4)に述べたように, $y_{0 c}=y_{0 B}^{U}$ のと き $z_{0}$ は無限大とするのが正しい. よってこの方法によ れば $y_{0 c}=y_{0 B}^{U}$ に対して $z_{0}$ を過小評価することになる. したがって設計上危険側の等危険度線を与える.ただし， 三角形ハイドログラフ，洪水継続時間とピーク流量の間 の完全線形従属性を仮定する場合には，この方法によっ て描いた等危険度線は厳密解に一致する.

以上より，座標值 $\left(y_{0 B}^{U}, z_{0 A}^{U}\right)$ に 1 より少し大きな値 $S_{f}$ を安全係数として乗じて, 少し安全側（右上）に移 動させ， $S_{f}$ の值をうまく見積もれば，等危険度線の近 傍の点を簡便に推定できる可能性がある．移動後の座標 を $\left(y_{0 B}^{U \prime \prime}, z_{0 A}^{U \prime \prime}\right)$ とすれば,

$\left(y_{0 B}^{U \prime \prime}, z_{0 A}^{U \prime \prime}\right)=S_{\lambda}\left(y_{0 B}^{U}, z_{0 A}^{U}\right)$

次に $z_{0}=0$ の場合について考える. 貯留流域のみにつ いて考えれば,

$y_{0 A}^{U}=\mathrm{F}_{y_{A}}^{-1}\left(x_{0}\right)=d$.

よって, 
$y_{0 C}^{U}=y_{0 A}^{U}+y_{0 B}^{U}$

よって等危険度線が $y_{0 c}$ 軸と接する点（ $\left.y_{0 c}^{v}, 0\right)$ につ いては,この方法によって描いた等危険度線は, 正しい 解に一致する.

以上より簡便法 II として，次の方法を提案する.

(1) $x_{0}$ を与える.

(2) 貯留流域, 残流域, 合流後の (A, B, C 点の) ピー ク流量の確率分布から, $y_{0 A}^{U}, y_{0 B}^{U}, y_{0 C}^{U}$ を求める（式 ( 9 ), (12)).

(3) 貯留流域総流量の確率分布から $z_{0 A}^{v}$ を求める（式 (34)).

(4) 安全係数 $S_{f}$ を乗じて $\left(y_{0 B}^{U \prime \prime}, z_{0 A}^{U \prime \prime}\right)$ を求める（式 (35)).

(5) 点 $\left(y_{0 B}^{U \prime}, z_{0 A}^{U \prime}\right)$ と $\left(y_{0 C}^{U}, 0\right)$ を放物線で結ぶ.

(6) $z_{0} \geqq z_{0 A}^{U \prime}$ の部分は $z_{0}$ 軸に平行な直線とする.

(7) $x_{0}$ を変えて多くの等危険度線を描けば, Fig. 5(b) と類似の等危険度線図が得られる.

(8) $d_{*}$ については簡便法 I と同様.

\section{（3）適用 例}

ピーク流量, 洪水継続時間が完全独立でかつともに指 数分布に従う場合 (Fig. 5(a), 式 (24)，(25) 参照)に 対して, 簡便法 I，II を適用した例が Fig. 6 である. 次 のようなことがわかる.

(1) 簡便法 I， IIによる解はともに厳密解にかなりよ く一致している.

(2) 簡便法 I (破線) はやや安全側の解を与える（式

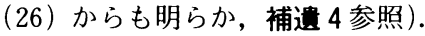

(3) 簡便法 II で $S_{f}=1.1$ とした場合（1点鎖線）はや や安全側, $S_{f}=1.0$ とした場合（2 点鎖線）は危険 側の解を与える.

さらに，次の点を注意しておく，ピーク流量, 洪水継 続時間が完全線形従属の場合は，これらの変量の確率分 布形にかかわらず簡便法 II（ただし $S_{f}=1.0 ）$ の解は, 厳密解に一致する。

以上より，結論として次のことがいえる.

(1) $S_{s}$ として適当な値を設定すれば，簡便法 IIによ り, 十分高い精度で近似的な等危険度線を描くこと ができる。

ここに, $S_{f}=1.0 \sim 1.1$

(2) 簡便法 I については，簡便法II よりやや面倒な手 法である，またやや安全側の等危険度線を与える。

(3) 簡便法は文字どおりきわめて簡便な実用的手法で あると同時に，明確な理論的裏付けが与えられてい る.

\section{5.おわりに}

残流域がある場合の等危険度線の性質について理論的
な検討を行った。またこれに基づいて，残流域がある場 合の等危険度線を描くための, 簡便な手法を提示した.

得られた結論については，3. , 4. の最後の部分にま とめている.

本論文および文献 2）で発表した研究は，文部省科学 研究費自然災害科学特別研究「都市河川の治水卜一タル システムの信頼性に関する研究（代表者：吉川秀夫早稲 田大学教授)」の補助を受けて行われた. また本研究の 遂行において, 山口嘉一氏（現・建設省土木研究所, 当 時大阪大学学生）とのディスカッションが大いに役だっ た. 記して謝意を表する.

$$
\begin{aligned}
\text { 補 } & \text { 遗 } 1 \\
P_{F}= & \operatorname{Prob}\left\{\left(y_{c}^{\prime}>y_{0 c}\right) \cup\left(z^{\prime}>z_{0}\right)\right\} \\
= & \operatorname{Prob}\left(y_{c}^{\prime}>y_{0 c}\right) \\
& +\operatorname{Prob}\left\{\left(y_{c}^{\prime} \leqq y_{0 c}\right) \cap\left(z^{\prime}>z_{0}\right)\right\}
\end{aligned}
$$

$y_{A}>d$ のとき，貯留施設が機能して放流量は $d$ とな る. $y_{A} \leqq d$ のきはピーク放流量は $y_{A}$. 残流域のピー ク流量は $y_{B}$ であるから, 仮定(6)～(8)より，

$$
\begin{aligned}
& y_{A}>d \text { のとき, } y_{C}^{\prime}=d+y_{B}, \quad z^{\prime}>0 \\
& y_{A} \leqq d \text { のとき, } y_{c}^{\prime}=y_{A}+y_{B}, \quad z^{\prime}=0 \\
& \text { よって, } \\
& P_{F}=\operatorname{Prob}\left\{\left(y_{A}>d\right) \cap\left(d+y_{B}>y_{0 c}\right)\right\} \\
& +\operatorname{Prob}\left\{\left(y_{A} \leqq d\right) \cap\left(y_{A}+y_{B}>y_{0} c\right)\right\} \\
& +\operatorname{Prob}\left\{\left(y_{A}>d\right) \cap\left(d+y_{B} \leqq y_{0 c}\right) \cap\left(z^{\prime}>z_{0}\right)\right\} \\
& =\operatorname{Prob}\left\{\left(y_{A}>d\right) \cap\left(d+y_{B}>y_{0 c}\right) \cap\left(z^{\prime}>z_{0}\right)\right\} \\
& +\operatorname{Prob}\left\{\left(y_{A}>d\right) \cap\left(d+y_{B}>y_{0 c}\right) \cap\left(z^{\prime} \leqq z_{0}\right)\right\} \\
& +\operatorname{Prob}\left\{\left(y_{A} \leqq d\right) \cap\left(y_{C}>y_{0 c}\right)\right\} \\
& +\operatorname{Prob}\left\{\left(y_{A}>d\right) \cap\left(d+y_{B} \leqq y_{0 c}\right) \cap\left(z^{\prime}>z_{0}\right)\right\} \\
& =\operatorname{Prob}\left\{\left(y_{A}>d\right) \cap\left(z^{\prime}>z_{0}\right)\right\} \\
& +\operatorname{Prob}\left\{\left(y_{A}>d\right) \cap\left(d+y_{B}>y_{0 c}\right) \cap\left(z^{\prime} \leqq z_{0}\right)\right\} \\
& +\operatorname{Prob}\left\{\left(y_{A} \leqq d\right) \cap\left(y_{C}>y_{0 c}\right)\right\}
\end{aligned}
$$

仮定9)が成立する場合，すなわち式（1）が成り立つ 場合について，式（42）のもつ意味を吟味する。

以下 $\mathrm{S}(）$ は，（）内の条件を満たす集合を意味 する.

a) $d>k_{A} y_{0 c}$ のとき

$\mathrm{S}\left(y_{A}>d\right)=\mathrm{S}\left(y_{c}>d / k_{A}\right)$

$\left.\mathrm{S}\left(d+y_{B}>y_{0 c}\right)=\mathrm{S} \mid y_{c}>\left(y_{0 c}-d\right) / k_{B}\right\}$

条件の $d$ の範囲に対して, 次式が成り立つ.

$d / k_{A}>\left(y_{0 c}-d\right) / k_{B}$

よって式（43）が成り立つとき，常に式（44）が成り 立つ.よって,

$\mathrm{S}\left\{\left(y_{A}>d\right) \cap\left(d+y_{B}>y_{0 c}\right) \cap\left(z^{\prime} \leqq z_{0}\right)\right\}$

$=\mathrm{S}\left\{\left(y_{A}>d\right) \cap\left(z^{\prime} \leqq z_{0}\right)\right\}$

この関係を式 (42) に入れれば,

$P_{F}=\operatorname{Prob}\left\{\left(y_{A}>d\right) \cap\left(z^{\prime}>z_{0}\right)\right\}$ 


$$
\begin{aligned}
& +\operatorname{Prob}\left\{\left(y_{A}>d\right) \cap\left(z^{\prime} \leqq z_{0}\right)\right\} \\
& +\operatorname{Prob}\left\{\left(y_{A} \leqq d\right) \cap\left(y_{c}>y_{0}\right)\right\} \\
= & \operatorname{Prob}\left(y_{A}>d\right)+\operatorname{Prob}\left\{\left(y_{A} \leqq d\right) \cap\left(y_{C}>y_{0 c}\right)\right\}
\end{aligned}
$$

式 (47) 右辺第 1 項は, 目標放流量よりもA点の自然 流量ピークの方が大きい上き，すなわち貯留施設が機能 するときは，常に失敗 (Failure) の側になることを意 味している、第 2 項はさらに，貯留施設が機能していな いのにC点で越流する確率が加わることを意味してい る.すなわち条件の範囲では貯留施設が全く治水機能を 果たさず，その築造が無意味であることを意味する。

b) $0 \leqq d \leqq k_{A} y_{0 c}$ のとき

上記の場合と同様に考えて,

$\mathrm{S}\left\{\left(y_{A} \leqq d\right) \cap\left(y_{c}>y_{0}\right)\right\}$

$$
=\mathrm{S}\left\{\left(y_{A} \leqq d\right) \cap\left(y_{A}>k_{A} y_{0 c}\right)\right\}=\phi
$$

$\mathrm{S}\left\{\left(y_{A}>d\right) \cap\left(d+y_{B}>y_{0 c}\right)\right\}=\mathrm{S}\left(d+y_{B}>y_{0 c}\right)$

ここに，фは空集合を意味する.

また $z^{\prime}>z_{0}$ のとき，常に $y_{A}>d$ であるから，

$\left.\mathrm{S} \mid\left(y_{A}>d\right) \cap\left(z^{\prime}>z_{0}\right)\right\}=\mathrm{S}\left(z^{\prime}>z_{0}\right)$.

よって,

$$
\begin{aligned}
P_{F}= & \operatorname{Prob}\left(z^{\prime}>z_{0}\right) \\
& +\operatorname{Prob}\left\{\left(d+y_{B}>y_{0 c}\right) \cap\left(z^{\prime} \leqq z_{0}\right)\right\} .
\end{aligned}
$$

\section{補 遗 2}

式（18）を（16）に代入して変形すると,

$P_{F 1}=\operatorname{Prob}\left(y_{A}>y_{A U}\right)=1-\mathrm{F}_{y_{A}}\left(y_{A U}\right)$

$P_{F 2}=\operatorname{Prob}\left\{\left(y_{A}>y_{A L}\right) \cap\left(y_{A} \leqq y_{A U}\right)\right\}$

ここに,

$y_{A L}=k_{A} / k_{B} \cdot\left(y_{0 C}-d\right)$,

$y_{A U}=\sqrt{2} \overline{k_{1} / k_{2} \cdot z_{0}}+d$

a) $y_{A U} \geqq y_{A L}$ のとき

$P_{F 2}=\mathrm{F}_{y A}\left(y_{A U}\right)-\mathrm{F}_{y_{A}}\left(y_{A L}\right)$

式（55）を（53）に（52）（53）を（3）または（16） に代入すると,

$$
\begin{aligned}
P_{F} & =1-\mathrm{F}_{y_{A}}\left(y_{A L}\right) \\
& =1-\mathrm{F}_{y_{A}}\left\{k_{A} / k_{B}\left(y_{0 c}-d\right)\right\}
\end{aligned}
$$

いま $y_{0} c ， z_{0}$ は固定されているので（式（2）参照）， $d$ が最小のとき $P_{F}$ は最小となる. よって式 $(4)$ と条 件を考慮すれば,

$d_{*}=\min d$, subject to $\left\{\begin{array}{l}y_{A U} \geqq y_{A L} \cdots \cdots \\ 0 \leqq d \leqq k_{A} y_{0 C}\end{array}\right.$

式 (57) に（54）を代入して整理し，（4）を考慮すれば,

$$
\begin{aligned}
k_{A} y_{0 c} & \geqq d \\
& \geqq k_{A} y_{n c}-k_{B} \sqrt{2 k_{1} / k_{2} z_{0}} .
\end{aligned}
$$

よって,

$k_{A} y_{0 c} \leqq k_{B} \sqrt{2 k_{1} / k_{2} z_{0}}$ のとき, $k_{A} y_{0 c} \geqq d \geqq 0$. よって,
( i ) $z_{0} \geqq 1 / 2 \cdot k_{2} / k_{1} \cdot\left(k_{A} / k_{B} y_{0 C}\right)^{2}$

のとき,

$d_{*}=0$

$P_{F *}=1-\mathrm{F}_{y_{A}}\left(k_{A} / k_{B} y_{0 c}\right)=1-\mathrm{F}_{y c}\left(1 / k_{B} y_{0 c}\right)$

これを式（5)，（9）に代入すると, 等危険度線の方 程式は,

$y_{0 C}=k_{B} y_{0 C}^{U}$

式（61）を（59）に代入すると,

$z_{0} \geqq z_{0 A}^{U}$

ここに,

$z_{0}^{U}=1 / 2 k_{2} / k_{1}\left(y_{0 c}^{U}\right)^{2}$

$z_{0 A}^{U}=1 / 2 k_{2} / k_{1}\left(y_{0 A}^{U}\right)^{2}=k_{A}^{2} z_{0}^{U}$

(ii ) $z_{0}<1 / 2 \cdot k_{2} / k_{1} \cdot\left(k_{A} / k_{B} y_{0 C}\right)^{2}$

のとき同様にして,

$d_{*}=k_{A} y_{0 c}-k_{B} \sqrt{2 k_{1} / k_{2} z_{0}}$

等危険度線の方程式は,

$z_{0} / z_{0}^{U}=\left\{\left(y_{0 c}^{U}-y_{0 c}\right) / y_{0 c}^{U}\right\}^{2}$

（67）を（66）を代入する亡,

$d_{*}=y_{0}--k_{B} y_{o c}^{U}$

式 (63), (67) 等を用いて, 式 $(65)$ の示す範井を $y_{0 c}$ の範囲で示せば,

$y_{0 B}^{U}<y_{0 C} \leqq y_{0 C}^{U}$

以上より等危険度線の方程式は, 式 $(61)$ ，(62）およ び (69), (67) で,このときの最適目標放流量は, 式 (60) および (68) で表わされる.

b) $y_{A U}<y_{A L}$ のとき

$P_{F 2}=0$ より,

$P_{F}=1-\mathrm{F}_{y A}\left(\sqrt{2 k_{1} / k_{2} \cdot z_{0}}+d\right)$.

$d$ が最大のとき $P_{F}$ は最小となる. あとは a) の場合 と同様の考察により, 式 $(59) \sim(69)$ が導かれる.

\section{補 遗 3}

a）貯留流域の等危険度線の方向微分

貯留流域のみの等危険度線を考える。この場合は module 1 に相当する. Fig. 1 (b) でA点の排水容量 $y_{0 A}$ は目標放流量 $d$ に一致させればよいから, 等危険度線 は $\left(d, z_{0}\right)$ 平面上に図示される.また目標放流量を放 流している間は安全であるから，危険度は「眝留施設が 満水になる確率」, すなわち $P_{F 1}$ となる。このときの安 全度を $x_{01}$ とする.

$\left(d, z_{0}\right)$ 点で等危険度線に沿う方向微分を考えると, $P_{F 1}$ は一定であるから, $\mathrm{d} P_{F 1} / \mathrm{d} s=0$. よって,

$$
\begin{aligned}
& \frac{\mathrm{d} P_{F 1}}{\mathrm{~d} s}=\frac{\partial P_{F 1}}{\partial d} \cos \alpha+\frac{\partial P_{F 1}}{\partial z_{0}} \sin \alpha \\
& \therefore \quad \frac{\partial P_{F 1}}{\partial d}+\tan \alpha \frac{\partial P_{F 1}}{\partial z_{0}}=0 \cdots \cdots
\end{aligned}
$$$$
\text { ここに， } \alpha \text { は } d \text { 軸と等危険度線のなす角. }
$$ 
等危険度線の方程式を $d$ に対する $z_{0}$ の関数, $z_{0}=z_{0}$ (d) を考えると,

$$
\begin{aligned}
& \tan \alpha=\left.\frac{\mathrm{d} z_{0}}{\mathrm{~d} d}\right|_{x_{01}=\text { const }} \ldots \\
& \therefore \quad-\frac{\mathrm{d} z_{0}}{\mathrm{~d} d} \cdot \frac{\partial P_{F 1}}{\partial z_{0}}=\frac{\partial P_{F 1}}{\partial d}
\end{aligned}
$$

ただし表記を簡単にするために，式 $(74)$ では $\left[x_{0}=\right.$ 一定］の条件は書いていない.

b) 最適条件

簡単のために, 以後式 $(26)$ の $(〜)$ を $(=)$ と書く.

$P_{F}=\operatorname{Prob}\left(z^{\prime}>z_{0}\right)+\operatorname{Prob}\left(y_{B}>\eta\right)$

ここに

$\eta=y_{0 c}-d$

式 $(75)$ で $\left(y_{0 c}, z_{0}\right)$ を一定とし, $(d, \eta)$ を変数 と考えれば, 右辺第 1 項は $d$ のみの, 第 2 項は $\eta$ のみ の関数となる.すなわち,

$P_{F}=P_{F 1}(d)+P_{F 2}(\eta)$

式 (76) の条件のもとに式 (77) を最小化するために, ラグランジュ乗数 $l$ を導入する.

$L=P_{F}+l\left(y_{0 c}-d-\eta\right)$

式 $(78)$ を $d, \eta, l$ で微分して 0 とおけば,

$\frac{\partial P_{F 1}}{\partial d}=\frac{\partial P_{F 2}}{\partial \eta}$

式 (79) に（74）を代入すれば,

$-\frac{\mathrm{d} z_{0}}{\mathrm{~d} d} \cdot \frac{\partial P_{F 1}}{\partial z_{0}}=\frac{\partial P_{F 2}}{\partial \eta}$

式（80）を満たす $d$ が $d *$ である.

c) $d_{*}=0$ となる条件

$z_{0}$ が大きい場合を考えているので， $d_{*}$ は小．ここで さらに $d_{*}=0$ となる条件を考える.Fig. 3 に示すように， $z^{\prime}$ は $d$ 以上の流量の和である. よって, $d \rightarrow 0$ のとき $z^{\prime}$ は総流量 $z$ となる. このとき, 式 $(76)$ より, $\eta=y_{0 c}$. このときの $y_{0 c}$ の值が $y_{0 c}$ の下限となる. これを $y_{0 c}^{L}$ と 書くことにする.

貯留流域の等危険度線において, $d=y_{0 A}=0$ のとき, 貯留容量 $z_{0}$ は, 等危険度線と $z_{0}$ 軸の交点の値 $z_{0}^{\nu}$ とな る.これを $z_{0 A}^{v}$ と書くことにする. 以下式 $(80)$ の各項 を評価する。

$$
\begin{aligned}
& P_{F 1}=1-\mathrm{F}_{z^{\prime}}\left(z_{0}\right) \cdots \ldots \ldots \ldots \ldots \ldots \ldots \ldots \ldots \ldots \ldots \ldots \ldots \ldots \ldots \ldots \ldots \ldots \ldots \ldots \ldots \ldots \\
& \lim _{d \rightarrow 0} \frac{\partial P_{F 1}}{\partial z_{0}}=-\lim _{d \rightarrow 0} \mathrm{f}_{z^{\prime}}\left(z_{0}\right)=-\mathrm{f}_{z}\left(z_{0 A}^{U}\right) \\
& P_{F 2}=1-\mathrm{F}_{y B}(\eta) \cdots \ldots \ldots \ldots \ldots \ldots \\
& \lim _{d \rightarrow 0} \frac{\partial P_{F 2}}{\partial \eta}=-\lim _{d \rightarrow 0} \mathrm{f}_{y_{B}}(\eta)=-\mathrm{f}_{y B}\left(y_{0 C}^{L}\right)
\end{aligned}
$$

あとは module 1 の等危険度線について $\mathrm{d} z_{0} / \mathrm{d} d$ を評 価すればよい。

著者らは module 1 の等危険度線は, 近似的に次式で
表わすことができることを示した ${ }^{21.31}$.

$$
\begin{aligned}
& z_{0} / z_{0}^{U}=\left\{\left(y_{0}^{U}-y_{0}\right) / y_{0}^{U}\right\} s . . . . \\
& \text { ここに, } \\
& z_{0}^{U}=\mathrm{F}_{z}^{-1}\left(x_{0}\right), \quad y_{0}^{U}=\mathrm{F}_{y}^{-1}\left(x_{0}\right), \\
& s=2 \sim 3(s=2 \text { が安全側 })
\end{aligned}
$$

これを module 2 の貯留流域の等危険度線として用い るには, $y_{0}^{v} を y_{0 A}^{U}, y_{0}$ を $d\left(\right.$ または $\left.y_{0 A}\right), z_{0}^{v} を z_{0 A}^{U}, x_{0}$ を $\chi_{01}$ とおけばよい.

これを $d$ で微分し, $d \rightarrow 0$ とおくと,

$\lim _{d \rightarrow 0} \mathrm{~d} z_{0} / \mathrm{d} d=-s \cdot z_{0 A}^{U} / y_{0 A}^{v}$

式 (82)，(84)，(86) を（80）に代入すれば,

$s \cdot z_{0 A}^{U^{\prime}} / y_{0 A}^{U^{\prime}} \cdot \mathrm{f}_{z}\left(z_{0 A}^{U^{\prime}}\right)=\mathrm{f}_{y B}\left(y_{0 C}^{L}\right)$

ここに,

$z_{0 A}^{U^{\prime}}=\mathrm{F}_{z}^{-1}\left(x_{01}\right), \quad y_{0 A}^{U^{\prime}}=\mathrm{F}_{\mathrm{yA}}^{-1}\left(x_{01}\right)$

式 $(87)$ で， $z_{0 A}^{U}, y_{0 A}^{v}$ は， $x_{0}$ でなく $x_{01}$ に対応する值 であることを注意しておく.

等危険度線が式 $(87)$ を満たす $\left(y_{0 c}, z_{0}\right)$ 座標上の点, すなわち $\left(y_{0 c}^{L}, z_{0 A}^{U}\right)$ に近づくとき, 最適目標放流量は 近似的に 0 となる．このときの危険度 $P_{F *}^{\prime}$ は,

$$
\begin{aligned}
& P_{F *}^{\prime}=P_{F 1}^{\prime}+P_{F 2}^{\prime} \\
& \text { ここに, } \\
& P_{F 1}^{\prime}=1-x_{01}, P_{F 2}^{\prime}=1-x_{02} \text {, } \\
& x_{02}=\mathrm{F}_{y_{B}}\left(y_{0 \mathrm{C}}^{L}\right) \\
& \text { よって安全度 } \boldsymbol{x}_{0}^{\prime} \text { は, } \\
& x_{0}^{\prime}=x_{01}+x_{02}-1
\end{aligned}
$$

式 (88)〜 (90) の’は, 近似解を意味する。

\section{補 遭 4}

式 (26) で $\left(z^{\prime} \leqq z_{0}\right)$ の条件を外すことにより．以下 の議論を展開している. この場合危険度 $P_{F}$ は過大に評 価される。よって $P_{F}$ あるいは安全度 $x_{0}$ を一定とすると き，必要施設規模は過大評価される。すなわち安全側の 施設規模を与える.

\section{羙文献}

1）日本河川協会編：改定建設省河川砂防技術基準（案）計 画編, 山海堂, pp.9 11, 1977.

2）江藤刚治・室田 明：一雨降雨の 1 確率模型, 土木学会 論文集, 第 345 号 / II -1, pp. 101 109, 1984 年 5 月.

3）江藤刪治・室田 明・柳本速雄：貯留施設と排水施設を

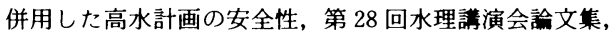
pp. $359 \sim 367,1984$ 年 2 月.

4）中西祐啓・江藤刚治・室田 明：等危険度線による遊水 地計画の安全度評価の例, 近幾大学理工学部研究辄告第 20 号, pp. 261 269, 1984 年 9 月.

5）未発表（山口嘉一：貯留施設と排水施設の間の治水機能 分担に関する研究, 大阪大学特別研究, 1984).

（1984.5.14 • 受付） 